\title{
Challenges and Opportunities of Business Models in Sustainable Transitions: Evidence from Solar Energy Niche Development in Lebanon
}

\author{
Houda Elmustapha ${ }^{1}$ and Thomas Hoppe ${ }^{2, *(D)}$ \\ 1 College of Business Administration (COBA), American University in the Emirates, \\ International Academic City, Dubai P.O. Box 503000, UAE; houda.elmustapha@aue.ae \\ 2 Department of Multi Actor Systems, Faculty of Technology, Policy and Management (TPM), \\ Delft University of Technology, Jaffalaan 5, 2628 BX Delft, The Netherlands \\ * Correspondence: T.Hoppe@tudelft.nl; Tel.: +31-15-278-2783
}

Received: 25 November 2019; Accepted: 31 January 2020; Published: 4 February 2020

\begin{abstract}
Although business models presumably have a prominent role in socio-technical change remarkably little research has been conducted in this domain, more particularly in the context of developing economies. In this paper, we tap into this knowledge gap and study business model components and the challenges they face. We argue that the market value of renewable energy technologies will increase when new business models are implemented to overcome financial and institutional challenges. We complement concepts of the business model literature with the insights from the sustainable transitions literature. This paper addresses two research questions: What are the challenges of business and financial models in the transition towards decentralized solar energy driven systems? And what are the promising opportunities for new business models in a developing country context? To answer these research questions, we use a case study research design focusing on niche market development of solar thermal and solar photovoltaic (PV) technology in Lebanon. Data collection involved analysis of relevant text documents and expert interviews with 30 informants across different groups of stakeholders. Data analysis involved qualitative interpretation of collected data against concepts from the business model and Strategic Niche Management literatures. The results show that business model challenges initially were highly dependent on donor aid, which contributed to the launch and network creation of niche markets. Later, a shift to micro-finance and business startup models was observed, which showed promising development. Knowledge transfer and community empowerment were found to play an important role in developing new business models that involve consumers more closely. As this development is expected to take place more often, we expect that new opportunity pathways will develop in developing economies like Lebanon.
\end{abstract}

Keywords: niche development; renewable energy; consumers; business model; sustainability; sustainable transition; solar energy

\section{Introduction}

Renewable energy sources have a crucial role in lowering carbon emissions and creating a sustainable environment. Both scholars and practitioners are interested in understanding sustainable transitions, i.e., large-scale disruptive change of economic sectors, such as transport or housing [1]. The crucial role of business models is recognized in driving sustainable transitions [2]. For instance, an innovative business model can result in diffusion of sustainable energy technologies in developing countries [3], and as a result can facilitate the uptake of electric vehicle technology [4]. According to Geissdoerfer et al. [5], a significant approach to achieve competitive advantage and improve 
sustainability is to move into using novel innovative business models. A review of innovative business models presented four generic configurations. They pertain to start-ups, business model transformation, business model diversification, and business model acquisition, indicating that business models can play a significant role in transition [6].

Recent reductions in the manufacturing costs of renewable energy technologies, like solar photovoltaic $(\mathrm{PV})$, along with clean energy incentives provided by the governments create opportunities for new business models $[7,8]$. This has resulted in increased integration of distributed energy technology such as solar photovoltaic (PV) and smart meters. However, to result in a wider societal transition through potential business models, key consideration needs to be given to the differences between business model and transition theory perspectives [2]. While transition theories amongst others examine functions of innovation systems [9], business models address issues like firm values and customer needs [10].

From this perspective it is relevant to look into niche market development. Niches can help renewable energy technologies to develop and expand, and replace current ones in the market. However, niches need different kinds of support. Kemp et al. [11] and Smith and Raven [12] address the level of niche shielding, that is, the amount of financial support a technology requires to stay competitive in the market. This occurs through protecting them from the regime pressures and creating space for novel business models to be developed and depends a lot on the context in which a given niche develops. In other words, certain contextual factors might be very influential in the enabling or disabling of niche development and indirectly prohibiting or pushing certain business models to develop. Moreover, the importance of business models is determined by their ability to commercialize technology and impose rules on different actors [13]. In this way, business models structure the activities in the niche and allow for value creation of a technology. Huijben and Verbong [7] address the importance of the contextual factors by referring to the policy context which they found to have an impact on entrepreneurs and the business model they operate in.

The present paper aims to understand the challenges and opportunities business models have in transitioning to renewable energy technologies, taking into account both theoretical foundations of niche development as well as contextual factors.

Wainstein and Bumpus [14] shed light on new business models in markets, in particular through focusing on their capability to increase customer participation. Moreover, when users get actively involved in shaping business models, it is likely that they will have a more clear understanding of their own needs and practices [15]. However, only recently scholarly attention has arisen that highlights the role between business models in sustainable transitions [16,17]. Thus far, little attention has been given to the roles business models have in the transition process to increase use of renewable energy technologies in developing countries, knowing that they are likely to suffer from higher levels of economic and political instability [18]. These countries typically rely more on foreign technologies [19] and donors tend to play a key role in market development [20]. Having said this, there are various differences between developed and developing countries which affect sustainable transition pathways, and the roles market actors can play. Accordingly, the challenges and opportunities that business models encounter in (sustainable) transition taking place in developing countries are unlikely to be the same as those in developed countries.

According to Engelken et al. [21], there are only a few studies that discuss the opportunities business models can create in markets, specifically markets in developing countries. Gabriel and Kirkwood [22] studied entrepreneurs in several developing countries and identified three types of entrepreneur business models. They pertain to (i) consultants, (ii) distributors, and (iii) integrators. The study also revealed that the type of model in each region depends on the support it receives from government and other institutions. Similarly, Jolly et al. [3] and Bryant and Romijn [23] discuss the opportunities of new business models by reflecting on the chances social entrepreneurs can have by addressing solar PV systems in India as a possible solution to giving households access to electricity supply, which in turn gives more weight to customer preferences $[24,25]$. Due to the specific nature 
and challenges in developing countries, Harish et al. [26] argue that micro-finance banks can play an important role as a sales channel of business models for renewables due to their local market knowledge. This approach was found feasible because developing countries often suffer from low security of energy supply, thus resulting in frequent blackouts and poor power quality. Contextual factors like this make the introduction of new business models for intermittent renewable energy sources into such fragile infrastructures both a challenge and an opportunity [26,27].

Tapping into this research gap, Sarasini and Linder [2] propose including business model concepts into the research agenda of innovation studies. In the present paper we follow their suggestion and look to address the how business model concepts can complement socio-technical transition concepts. Next to discussing the relevance of business model concepts in sustainable transitions we provide an illustrative case study of solar energy niche development (i.e., solar thermal systems and solar photovoltaics) in Lebanon. The two research questions that are central to this paper are: (1) What are the challenges of business and financial models in the transition towards decentralized solar energy driven systems? (2) And what are the promising opportunities for new business models in a developing country context?

To answer the research questions of this paper several steps were taken. As a starting point we address a number of papers from both the transition literature and the business model literature, paying special attention to articles combining both areas of research and the role that business models have in sustainable transitions. The subsequent sections will address the theoretical background for this paper consisting of insights from both the literature on sustainable transitions and the literature on business models. Section 3 discusses aspects that the business model literature and the sustainable transitions literature have in common. Section 4 presents the research design and methodology applied in this paper, followed by Section 5, in which the results of the case study are presented. In Section 6 the results are discussed positioned in relevant academic debates. Section 7 concludes the paper and presents recommendations for further research.

\section{Theoretical Background}

\subsection{Socio-Technical Transitions}

Socio-technical transition theories are used to study the shifts within large socio-technical systems [28], transportation [29], and other societal utilities [30]. Transition theory perspectives employ a common set of concepts such as socio-technical systems, niches, regimes, and landscapes in order to study the dynamics of sustainable transitions. Transition occurs when these three levels interact, that is, radical innovations require protection to mature, and if a niche matures successfully it will cause regime to change which in turn builds up tension to even change the landscape level [31]. Socio-technical approaches to transitions often focus on the role that technology and technological innovation play in fulfilling societal functions. According to Schot and Geels [32], sustainable development might be achieved when the social and technical dimensions co-evolve.

Theoretical frameworks on sustainable transitions strive to understand and explain system transformation and address how to manage sustainable system transformations. Specifically, Strategic Niche Management (SNM), for instance, focuses on niche-level activities such as learning, networking, and visioning [11,32]. SNM argues that radical innovations require niches to be nurture in order to succeed [32]. Moreover, breakthrough technologies are likely to change mainstream markets, that consist of existing infrastructure, user preferences, and have multiple cultural meanings attached to it $[11,12]$. These technologies will start to develop within niches, that can be seen as protective spaces, and that operate within a unique set of rules [7]. Niches take the form of protected spaces where experimentation occurs and are expected to result in innovations. There are certain functions that spur innovations, and functions that are associated with the diffusion of technological innovations [33]. Examples pertain to research and development, financing of the innovation process, and fostering new fields for innovation development (such as entrepreneurial experimentation). 
From a socio-technical perspective, technological innovations themselves play a key role in fulfilling societal needs, but the functioning of a technology in a socio-technical system basically depends on other elements, such as regulations, user practices, or cultural meaning [16]. That is, transition does not only involve changes to the technology itself, but also changes to the environment in which it has a function, and other elements of a socio-technical system, such as user practices and regulations [34]. In a similar sense, a shift towards sustainable development requires drastic change in both production and consumption structures and patterns [35].

Although transition research mainly focuses on the role of technological innovations, it is recognized that technological innovations alone are not sufficient to induce socio-technical change [35,36]. Similarly, the International Energy Agency (IEA) [37] argues that market uptake of energy efficient technologies is not moving fast enough, assuming that when the industry and the residential sector adopt such technologies it will reduce the energy demand considerably.

The niche processes of solar energy technology require business models that handle perceived risks and remove the high investment costs and space requirements of solar energy systems [7]. Moreover, business model innovation is considered an important driver in speeding up the low carbon power system transition [14].

From a market perspective, renewable energy technology requires business models that have the ability to effectively commercialize them and make them compete with available-mostly conventional-technology. Therefore, given the importance of the activities niche actors have in disrupting socio-technical regimes, we will reflect on the business model concept for transition.

\subsection{Business Models}

Business models play a significant role in capturing the value of an innovative idea through linking it to customers' needs [10,38]. Teece [10] defines a business model as the design or architecture of value creation, delivery, and capture mechanisms. In a similar vein, Bidmon and Knab [16] argue that business models address the process by which firms create and capture value. Business models have received various definitions and have been applied from different theoretical perspectives [39]. Despite the fragmentation among definitions, business models are described as market devices that shape how an organization creates, delivers, and captures value [40]. However, there is certain agreement on the basic conceptual meaning of a business model that describes how firms create and capture value [36]. Business models not only deal with linear value creation of a firm from suppliers to customers, but also with complex transactions within value-networks concerning value creation for multiple parties in those networks [40]. Osterwalder [41] provides a means to differentiate between different business model types by constituting nine building blocks. Among those, the product block includes the business area and the value proposition that is offered to the market. Another block is the customer interface, with the aim of identifying targeted customers, selecting distribution channels to reach them, and building relationships with them. Infrastructure management includes the network that the firm uses to deliver created values. The financial blocks include the cost structure and revenue streams. Osterwalder and Pigneur [42] address the business model blocks that business enterprises apply to create, deliver, and capture value.

\subsection{Business Models and Socio-Technical Transitions}

Bidmon and Knab [16] base their business model definition on the functional perspective of transforming resources into outcomes. They propose that the core function of a business model within a socio-technical system is to commercialize innovative technology developed at the niche level. In this sense business models are used in non-technological niches that have a higher stability level than niches that address (immature) technological innovations. Business models also contain deep and robust expectations that are well-articulated and communicated. As such they can be seen to entail an advanced stage of second order learning that involves social networks with a considerable breadth. A major component of a business model is generating value for customers by finding a solution for 
problem they encounter in their lives [43]. However, to understand and apply a business model perspective, Provance et al. [44] argue that contextual factors should also be taken into consideration.

Bidmon and Knab [35] propose that business models act as a crucial point of communication between actors. Thus, they support the articulation of visions and expectations of certain technologies. This allows the articulation of value creation and the value capture mechanism for a technology among innovation actors. In addition, business models are less likely to have a role in building social networks [41], but may increase communication between different innovation network actors, which will subsequently support learning processes and social network formation, and by doing so is more likely to attract consumer attention and investors [13]. Furthermore, business models improve learning processes between organization by acting as a knowledge hub [35] that creates competitive advantage for new technologies and attracts new actors to the network [14]. Hence, once a technology is coupled with an innovative business model it becomes more likely to be adopted by (a greater pool of) actors, and is therefore more likely to diffuse across markets.

Bidmon and Knab [16] explain that improvements occurring at business model levels will result in change in technological niches contributing to the emergence of dominant technological designs. This means that actors should not cling too much to existing business model logic (e.g., relying on donor funds in the case of firms in many developing countries), but should rather pave the way for new business models to emerge [45].

\section{Characterization of the Business Model in Solar Energy Niche Cases}

Boons et al. [46] address the importance of business models and argue that they should even be considered part of socio-technical systems. In order to create a higher market uptake of renewable energy technologies, better infrastructures, more customer oriented regulation, and support mechanisms are required due to their direct influence on the success of a business model [7].

Just as niche experimentation is designed to help a given niche compete with conventional technologies in markets, so is experimentation in the business model [10]. Transition theories discuss the importance of entrepreneurial activities in initiating change and supporting the diffusion of innovations [2]. These activities are referred to as 'entrepreneurial experimentation'. This includes testing the potential of new technology to disseminate "new knowledge, networks, and markets into concrete actions to generate new business opportunities" [9] (p. 421). Experimental activity will result in attracting a range of new stakeholders, with new ideas and new capabilities [2].

Koubaa [47] argues that entrepreneurial activities in developing countries suffer from various challenges such as access to finance, lack of investor protection and government regulations, political instability, and access of information for new business ideas. These challenges strongly influence the entrepreneur's ability to exploit opportunities. Thus, without experimenting and learning about a business model, many market opportunities are basically missed [43].

Just as demonstrations and experimentations occur at the niche level business models are also shaped in experimental ways. As a starting point, hypotheses are generated to be tested later, to be elaborated and reformulated [48]). That is, after experimentation is done, further evaluation, research, and development take place to address market and consumer needs. This shows that business models play a significant role in facilitating various activities in internal niche process within the SNM framework. According to Tolkamp [43], SNM is important to business model development because it provides guidelines for business model developers on how to organize certain niche activities. For the purpose of defining a business model just like processes taking place at the niche level, a learning process of trial and error takes place regarding business models. Because a business model takes the form of an experimental process, it does not only facilitate single loop learning, but also double-loop (second order) learning [49]. Once certain lessons are learned, the likelihood increases that a more customer oriented business model will develop [10]. This also allows for integrating the three core internal elements of the SNM framework (i.e., aligning expectations, network formation, and learning) into the business model perspective. 
When perceiving the business model perspective from a broader societal context it is contextual factors that affect the success of business models $[7,10]$. Since a technology depends on its intended consumers can be much more than just end-users of energy involved in the process of gaining more knowledge and value [50]. However, even when business models focus on fulfilling consumer needs, behavioral challenges might hinder market uptake [38]. For this reason, gaining a better understanding of customers' behavior is likely to increase their awareness of environmental problems [51]. For consumers to use energy efficient technologies, a better fit with the social context and lifestyle of potential end users is required [52]. However, the assumed benefits of these kinds of technology need to be communicated to the consumer before it can be imagined, perceived, assessed, and eventually accepted and used.

\section{Research Design and Methodology}

A case study research design is used to provide new insights on the challenges and opportunities business models for sustainable niche market development encounter in a developing economy context. This research design was selected for its strength to address and assess rich, descriptive data of a specific phenomenon under study in its context resulting in comprehensive understanding [53]. The case study of business models in the Lebanese solar energy market serves here as "an empirical inquiry that investigates a contemporary phenomenon within its real life context; especially when the boundaries between the phenomenon and context are not clearly evident" [54] (p. 13). As the aim of this paper is to understand the opportunities and challenges that business models have in the transition literature, we look to explore similarities between the two literature concepts and to reflect on the core concepts [2]. We particularly address risk association that manifests with business models in developing economies $[55,56]$.

\subsection{Case Study Selection}

The Middle East and North Africa (MENA) region is rich in solar radiation, thus making adopting solar energy technologies potentially attractive [57,58]. However, to our knowledge, no empirical studies have reflected on the sustainable transition framework and business models in developing economies of the MENA region. Because of this academic knowledge gap, Lebanon is used in this study as an illustrative case. The country has abundant solar radiation yet relies on fossil fuels imported from neighboring countries for energy generation. Moreover, Lebanon has unstable political and economic conditions, thus showing a hostile environment to green innovations [59]. Despite the ongoing national initiatives in the country, Lebanon needs new business models that involve consumer participation to develop renewable energy technology markets. For these reasons, this country is selected to present a case study of the complexity of market development and to serve as an example case for other developing countries of similar geo-political and socio-economic dimensions.

\subsection{Data Collection and Analysis}

To answer the questions on the challenges and opportunities business models encounter in sustainable transition in a developing economy context, a qualitative research approach is selected. This research approach aims to answer research questions of "what", "why", and "how", taking into consideration the social context to provide a rich understanding of the problems and potential in a given area, requiring the collection and analysis of detailed, rich, contextualized data [60].

For data collection we relied on two previously conducted empirical case studies that address the diffusion and transition of solar energy technologies in Lebanon $[19,20]$. Face to face, semi-structured interviews were conducted between February and March 2017, that lasted between 45 to 60 minutes each. Interviews were conducted in the English language and held with 30 informants across different groups of stakeholders (i.e., consultants, solar energy technology providers, consumers, NGOs, financing, public sector institutes, and project managers). To generate a rich understanding of the solar energy niches and the development of business models in the Lebanese market, the primary 
researcher of this study (the first author) participated in several solar energy project meetings. Data triangulation of different sources of evidence [61] was applied as interview data were complemented with information about implemented and alternative business models from secondary sources, such as online publications and newsletters and other professional publications from ongoing programs (implemented by the United Nations Development Program) and semi-public institutions (such as national energy efficiency center) in the renewable energy industry.

As a first step in the data analysis we brought the business model and SNM perspectives together following a literature study of the available academic literature (as presented in Sections 2 and 3). Then, we built on a qualitative analysis of the case study on the development of solar energy niches in Lebanon. This serves as an illustrative example that describes previously implemented and potential future business models in a developing economy and their interconnection with niche development. The key terms of analysis were based on key themes of the business model canvas [42] and core concepts presented in the literature study, and the illustrative examples against these theoretical propositions were later evaluated.

\section{Results}

\subsection{Business Models of Solar Energy Niches in Lebanon}

This section starts with presenting business models and their respective challenges applied in the Lebanese context in which the solar niche development took place, summarized in Table 1. Building on this, the main elements of the business model relevant to the Lebanese context are summarized in Table 2. These elements provide similarities with the transition concept as discussed earlier in the literature section. Furthermore, understanding the business model components will provide a clear direction towards addressing the opportunities that pertain in a developing country context, in particular Lebanon as discussed in this section of this paper. The demonstration of these projects helped increase the technical expertise of technology suppliers who were engaged in installations [19]. On the other hand, the demonstration projects at the niche level increased awareness of consumers. These projects pushed for financial models and more sustainable models in the solar energy market.

Table 1. Overview of financial models applied in Lebanon regarding solar energy technology.

\begin{tabular}{|c|c|c|c|c|c|c|}
\hline $\begin{array}{l}\text { Type of } \\
\text { Model }\end{array}$ & Owner & Provider & Intermediary & $\begin{array}{l}\text { Type of } \\
\text { Payment }\end{array}$ & Maintenance & Challenges \\
\hline $\begin{array}{l}\text { Donor aid } \\
\text { business } \\
\text { model }\end{array}$ & $\begin{array}{l}\text { End user } \\
\text { becomes } \\
\text { owner }\end{array}$ & $\begin{array}{l}\text { Chosen through } \\
\text { funding } \\
\text { government/agencies }\end{array}$ & $\begin{array}{l}\text { Local } \\
\text { authority or } \\
\text { project } \\
\text { management } \\
\text { of programs }\end{array}$ & Free & $\begin{array}{l}\text { Consumers } \\
\text { responsible } \\
\text { for } \\
\text { maintenance }\end{array}$ & $\begin{array}{l}\text { Low awareness from customers } \\
\text { on the importance of regular } \\
\text { maintenance. } \\
\text { Lack of a sustainable finance } \\
\text { mechanism. } \\
\text { Available products only } \\
\text { originate from donor countries, } \\
\text { with limited variety in quality. }\end{array}$ \\
\hline $\begin{array}{l}\text { Local based } \\
\text { collective } \\
\text { model }\end{array}$ & $\begin{array}{l}\text { End user } \\
\text { becomes } \\
\text { owner }\end{array}$ & $\begin{array}{l}\text { Technology providers } \\
\text { in market }\end{array}$ & $\begin{array}{l}\text { Project } \\
\text { management } \\
\text { of programs }\end{array}$ & Loan based & $\begin{array}{l}\text { Consumer } \\
\text { responsible } \\
\text { for } \\
\text { maintenance }\end{array}$ & $\begin{array}{l}\text { Lengthy application and } \\
\text { selection processes. } \\
\text { No clarity in selection criteria. }\end{array}$ \\
\hline $\begin{array}{l}\text { Collective } \\
\text { micro-finance } \\
\text { business } \\
\text { model }\end{array}$ & $\begin{array}{l}\text { End user } \\
\text { becomes } \\
\text { owner }\end{array}$ & $\begin{array}{l}\text { Contracting } \\
\text { collectively with same } \\
\text { technology providers } \\
\text { in market }\end{array}$ & $\begin{array}{l}\text { Banking } \\
\text { sector }\end{array}$ & Loan based & $\begin{array}{l}\text { Consumers } \\
\text { responsible } \\
\text { for the } \\
\text { maintenance }\end{array}$ & $\begin{array}{l}\text { Low acceptance from } \\
\text { customers. } \\
\text { Low awareness of benefits. } \\
\text { Lack of availability of clear } \\
\text { financing model in terms of } \\
\text { applying for loans. }\end{array}$ \\
\hline $\begin{array}{l}\text { Micro-financed } \\
\text { and startup } \\
\text { business } \\
\text { model }\end{array}$ & $\begin{array}{l}\text { End user } \\
\text { becomes } \\
\text { owner }\end{array}$ & $\begin{array}{l}\text { Technology providers } \\
\text { in market }\end{array}$ & $\begin{array}{l}\text { Banking } \\
\text { sector }\end{array}$ & $\begin{array}{l}\text { Cash } \\
\text { sales/loan } \\
\text { based }\end{array}$ & $\begin{array}{l}\text { Consumer } \\
\text { responsible } \\
\text { for } \\
\text { maintenance }\end{array}$ & $\begin{array}{l}\text { Limited availability of quality } \\
\text { control practices. } \\
\text { Restricted alignment in vision. }\end{array}$ \\
\hline
\end{tabular}


Table 2. Characteristics of business models used in the Lebanese solar energy niche development.

\begin{tabular}{|c|c|c|c|c|c|}
\hline $\begin{array}{l}\text { Business } \\
\text { Model Block }\end{array}$ & & Characteristics & Donor Aid & $\begin{array}{l}\text { Locally Based } \\
\text { Initiatives }\end{array}$ & $\begin{array}{l}\text { Micro-Finance and } \\
\text { Startup Approach }\end{array}$ \\
\hline \multirow{19}{*}{$\begin{array}{l}\text { Infrastructure } \\
\text { Management }\end{array}$} & \multirow{7}{*}{ Key Partners } & Technology providers & & * & * \\
\hline & & Government institutions & $*$ & * & \\
\hline & & NGOs & & * & * \\
\hline & & Local incubation centers & * & * & * \\
\hline & & Financial institutions & & * & * \\
\hline & & Local and foreign technicians & * & * & * \\
\hline & & International fund providers & * & * & * \\
\hline & \multirow{7}{*}{ Key Activities } & Installation & * & * & \\
\hline & & $\begin{array}{l}\text { Limited networking between } \\
\text { installers and technically } \\
\text { experienced grant providers }\end{array}$ & * & & * \\
\hline & & Active networking & & $*$ & * \\
\hline & & $\begin{array}{l}\text { Project implementation and fund } \\
\text { management }\end{array}$ & & * & * \\
\hline & & Project bidding & & * & \\
\hline & & Grant supported retail sales & & * & * \\
\hline & & Idea creation & & * & \\
\hline & \multirow{5}{*}{ Key Resources } & Skills training for locals & & * & \\
\hline & & Grants & * & * & * \\
\hline & & Learning on field installations & * & * & * \\
\hline & & Financing mechanism & & * & $*$ \\
\hline & & Active knowledge transfer & & * & * \\
\hline \multirow{5}{*}{ Product } & \multirow{5}{*}{$\begin{array}{l}\text { Value } \\
\text { Propositions }\end{array}$} & Knowledge sharing & & * & \\
\hline & & $\begin{array}{l}\text { Dependent on identifying the } \\
\text { right connection for initiating the } \\
\text { installations }\end{array}$ & & * & * \\
\hline & & Contacts to reliable suppliers & & $*$ & \\
\hline & & $\begin{array}{l}\text { Grants reliant on approved } \\
\text { suppliers }\end{array}$ & & * & * \\
\hline & & Fully owned systems & * & * & * \\
\hline \multirow{11}{*}{ Customer } & \multirow{2}{*}{$\begin{array}{l}\text { Customer } \\
\text { Relationships }\end{array}$} & $\begin{array}{l}\text { Advertising: word of mouth, } \\
\text { billboards, projects websites }\end{array}$ & & * & * \\
\hline & & $\begin{array}{l}\text { Direct relationships with end } \\
\text { users }\end{array}$ & & * & * \\
\hline & \multirow{3}{*}{ Channels } & Use bids to reach customers & & * & \\
\hline & & $\begin{array}{l}\text { Relying on word of mouth to } \\
\text { reach customers }\end{array}$ & & * & * \\
\hline & & Direct transactions & * & * & * \\
\hline & \multirow{6}{*}{$\begin{array}{l}\text { Customer } \\
\text { Segments }\end{array}$} & Residential end users & * & & * \\
\hline & & Governmental end users & $*$ & & * \\
\hline & & $\begin{array}{l}\text { Medium-sized commercial end } \\
\text { user }\end{array}$ & & * & * \\
\hline & & Lower income end users & * & & * \\
\hline & & Industrial end users & & * & * \\
\hline & & Innovative community members & & & * \\
\hline \multirow{8}{*}{$\begin{array}{l}\text { Financial } \\
\text { Aspects }\end{array}$} & \multirow{4}{*}{ Cost Structure } & Reduced priced system & * & * & * \\
\hline & & Logistics and operations & * & * & \\
\hline & & Human capital subcontracts & & * & \\
\hline & & Cost of advertising/publishing & & * & $*$ \\
\hline & \multirow{4}{*}{$\begin{array}{l}\text { Revenue } \\
\text { Stream }\end{array}$} & Knowledge transfer & & * & \\
\hline & & Increased sales/loans access & * & * & * \\
\hline & & Overseeing installations & & * & * \\
\hline & & Limited infrastructure integration & * & * & \\
\hline
\end{tabular}

${ }^{*}$ ) Shows the presence of the respective characteristic in business model types.

With the start of the solar thermal niche, investment projects were supported by non-governmental organizations and donor aid from countries like China, Spain, Turkey, Sweden, and Greece in the form of donations of individual systems from the nation states [62]. In 2009, one of the key projects was a United Nations Development Programme (UNDP) funded project which installed large scale solar thermals and PVs on public buildings. The installations were fully funded by foreign investors. This triggered the government to launch financial incentives for household and corporate installations. The demonstration projects and workshops funded by foreign investors increased the technical knowhow among technology providers [19].

To move away from fully funded projects, two new funded projects (Med Solar and Country Energy Efficiency and Renewable Energy Demonstration Project for the Recovery of Lebanon (CEDRO4)) 
facilitated a new financial model that required the private sector to cover their investments [63]. Unlike the pure grant funding, this approach guaranteed a more sustainable business model in order to open up new market opportunities: a gradual shift from completely grant-financed solar energy projects to a more sustainable financing model which also increasingly engaged the private sector to finance these investments. This shift was based on the need to change ongoing market approaches, thus, meeting the customers' needs.

A Global Environment Facility (GEF) funded project on Small Decentralized Renewable Energy Power Generation (DREG) provided a complementary grant co-financing scheme as an advancement to the previous financing mechanism [20]. This project triggered a transition away from pure grant-funding for renewable energy investments towards more sustainable business models to open up new market opportunities and increase commitment of end users. Thus, proving that new models that take into consideration the needs, capabilities, and challenges facing end users need to be considered.

The interviews and reviewed documents identified the following historical and new approaches (showcasing finance and knowledge transfer). In the past, the finance approaches involved active shielding, such as full donor support by international organizations. The funders were able to fill a gap that the Lebanese market was not ready yet to fill. This shows a need to have creative solutions in place that are tailored to the end users' needs. The approaches that were used are presented in Table 2.

\subsubsection{The Donor Aid Model}

The donor driven approach was the first form of business models applied in Lebanon. Although it did not ensure financial stability in the implemented projects, the donor aid business model contributed to the launch of the solar energy market. This form of business model relied on foreign funds, which did not ensure a sustainable financial flow as priorities of the funder shifted and the systems implemented depreciated over time. The end users (both in the commercial and the residential sectors) directly benefited from the installed system either with low cost or without cost. End users were set fully in charge of the system maintenance and usage. One of the drawbacks of such business models is low commitment of end users towards maintaining the solar energy systems in a good functional state. The value proposition of this business model promised end users no investment cost and full ownership of solar energy systems. However, quality and country of origin of the systems was limited to donor countries, offering customers limited choice.

The role of the donor aid business model was to successfully introduce the solar energy systems to the Lebanese market and increase the knowhow of local technology providers. The key resources in this business model pertained to the financial power of the funders, the products of technology providers, the knowhow of the project managers, and the underlying network of actors involved in the projects' implementation. The key activities were finding potential end users for systems' installations and the actual interaction between different local and international actors, thus resulting in knowledge transfer from one party to another. The distribution channel to deliver these activities and to ensure interaction between network actors themselves and potential customers, was done through the managing body of funded programs and the National Conservation Center. In its early stages, the customer segment of this business model mostly involved the residential sector. At a later stage, industry (i.e., public utilities) also became involved.

The donor funding created a protective space for the niche technologies. This was critical at the first stages of the products launch because it was aimed at reducing the risks associated with early investment in new business models. The early donor finance model can be regarded as supportive to organizing experiments that contributed to creating a learning environment and a basis for future finance approaches. The experiences and challenges that the solar energy project encountered included limited awareness and expertise by both end users and suppliers, and low performance of systems due to low quality (also related to the country of origin). This can be seen as a base from which new and more sustainable approaches were developed. Arguably, this can be viewed as second order learning taking place. 


\subsubsection{Locally Based Collective Project Business Models}

Learning from these experiences, a new finance model paved the way to provide end users with a more active role in localized projects. Actors aimed at creating a more active role for end users. In this model, customers would finance their systems through low interest loans supported by the government. Yet, to make the investments more attractive to customers, a foreign grant of up to $25 \%$ of the total investment was to be provided. This shift was based on the UNDP and funder specifications to engage the private sector in investments and to ensure their commitment to the projects through financing their own investments. This proved to be essential to increase end users' commitment to the installed systems. The locally based collective business model was mainly applied to private corporations (over different industrial sectors) and did include installations of large scale decentralized solar PVs. The financing process would then start by evaluating projects requesting the smallest grant contribution for the projected energy generation, which would then be prioritized. The customers' proposals specify the financial and technical specifications of the systems along with the calculations of the annual yield [64]. Besides this, the National Conservation Center would approve and verify the proper installations of the systems prior to releasing the foreign grant. By the end of the projects' implementation term, the system would fall under the complete ownership of the end user who in turn becomes responsible for its maintenance.

The value proposition of this business model was mostly based on the ownership of a clean energy system with relatively acceptable cost of investment given the low interest loans and the grant. The most common form of inter-actor interaction was between technology providers, project managers, and funders on the one hand, and between the technology providers and the end users on the other. Technology providers were interested in taking part in large-scale decentralized projects managed by UNDP provided by foreign funds. This was expected to improve their market status and increase their technical knowhow. As from 2014, technology providers taking part in demonstration projects promised potential customers a relatively low cost and high quality solar system. After getting approval from program managers and funders, the providers had to initiate contact with potential end users to also receive their approval and start the implementation process. However, various coordination activities (such as reporting about potential customers or providing technical and financial studies of investments) took place between the technology providers and the project managers. The distribution channels to cover these activities were managed by project managers who acted as intermediaries between the funders on the one side and the technology providers and customers on the other side. One-on-one interactions between actors of each side and the intermediary occurred through various monitoring and coordination meetings. The most vivid challenges in this model pertained to the absence of clarity for the selection process of beneficiaries. Although the end users benefitted from the technical expertise of installers, the selection of locally based firms that would benefit from the system installation was mostly reliant on the capacity within available programs.

\subsubsection{Micro-Finance and Entrepreneurship Project-Based Business Models as Promising New Models}

Interactions and actor network building were established through previous finance approaches (i.e., donor aid and locally based business models). This was part of a nurturing process resulting in niche market development. However, the visions of the actors were not aligned to proper nurturing of the niche in all of the stages. This was observed through the various projects implemented simultaneously in the market. The actions of actors were coordinated to meet the desired outcomes of projects instead of trying to find a common vision that would serve overall niche development. Knowledge exchange started with donor-based networks but was eventually promoted with locally based projects and semi-funded grants. The funders supported network formation, knowledge transfer, and end users' involvement. At a later stage, the funders started supporting the community involvement through the incubation centers, creating ideas, and supporting the development of networks.

Micro-financed business models were based on 'in cash' investments and subsidized loans. This resembled residential and corporate end users who own and finance solar energy systems with full 
responsibility for installation and maintenance. Unlike the previous two business model types in which project managers are typically held responsible to coordinate with technology providers for the installation of solar systems, the end user is solely responsible for the installation of the systems in the micro-finance business model. This business model aims to reduce high upfront costs, mitigate financial risk, and increase end users' access to renewable energy technologies. Thus, solar thermal technology financing mechanisms in this model would act as a catalyst for market development. In this model, end users are subjected to subsidized loans (at a $0 \%$ interest rate). In the case of solar thermal systems in Lebanon, residential end users received a $\$ 200$ grant for the installation of a qualified system from a selected technology provider. The bank then deducted this amount from the final installment of a qualified solar system. In the case of collective solar thermal and solar PVs (small and large scale), another financing mechanism (through the National Energy Efficiency and Renewable Energy Action-NEEREA) was launched to the market in 2010. This financing mechanism offered end users subsidized loans for a period of up to fourteen years with a $0.6 \%$ interest rate. It was offered at commercial banks and supported by the Central Bank of Lebanon, targeting residential, commercial, and industrial users for all renewable energy systems.

The initiatives launched aimed to accelerate the uptake of renewable energy systems installations in the Lebanese market. This was verified by the main value proposition used in this type of business model being "Energy for free, and a solar thermal system for every household" (in the case of residential solar thermal systems). Although this model played a significant role in developing the renewable energy market in Lebanon, it suffered from problems, such as lengthy procedures (two to three months). This challenge was demonstrated through the application process, for instance, in order to apply for a NEEREA loan, potential end users were requested to provide the commercial bank a technical report through a technology provider which included a feasibility study (for installations up to 20 Million USD) which should include complete technical and financial analyses. In the case of reports that were submitted well (and found eligible), micro-finance institutes would provide guarantees for the bank, thus making the lending process less risky for the bank through ensuring the reliability of customers in re-payment of the loan. In turn, the commercial bank would send the report to the National Conservation Center for revision.

The role of this model was to hold customers responsible for finding and contacting technology providers and for selecting the commercial bank that would grant the loan for solar system installation. Furthermore, technology providers would act as intermediaries between customers and banking institutes in the case of both small- and large-scale solar PV installations.

The funders gave more attention to the need for capacity building and creation of a market catalyst. The Strategic Hub for the Analysis and Acceleration of the Solar Sector in Mediterranean region project (SHAAMS) in 2014-which was partly implemented by Berytech-supported innovative ideas from entrepreneurs through a foundation that allocates a specific fund for research and development, supporting innovation adoption in the Lebanon. This approach triggered another form of business model that enables entrepreneurs and individuals to be part of the system to create change and involve consumers more in the market, and more specifically in knowledge transfer. For example, crowd powered startups created platforms that are aware of the particular space and financing challenges that the Lebanese consumers have encountered in the past few years. These platforms would invite customers to find the right renewable energy solution for their available space and budget, shop for a loan, and hire a design office, equipment supplier, and contractor to get solar panels installed on rooftops. These startups act as one-stop-shops for designing, securing, and financing. Individual approaches were applied by a number of municipalities in small villages in the south of Lebanon where they took personal initiatives for the community to collaborate with banks to ensure financing and connected with local communities to increase knowledge transfer. Municipalities then ensured implementation of solar systems on roof tops of residential consumers, via coordination with the aim to finalizing the financial processes. This was expected to pave the way for a new level of this model that would use digital technologies to link users to their respective municipality. PV systems would be 
installed on individual owned land properties, and the systems would operate under the approval of the respective municipality. The municipality would then become responsible for providing users with a map of the PV systems nearby. However, further empirical research is required to provide more precise quantitative data to measure the feasibility and success of such a model in the Lebanese context.

\subsubsection{Comparative Analysis of the Three Business Models}

Based on the overview of challenges addressed in Table 1, and the specific business model characteristics addressed in Table 2, we deduce the interrelation between the two. The challenges manifested in the donor based business model mostly pertain to limited awareness and expertise in market. The key partners involved were limited to specific donor countries, with limited learning experience and limited exchange of technical expertise (often restricted to mere intra-project expertise exchange). This was reflected in the key resources provided for local actors, which suffered from low diversity in partners. The locally based business model encountered different challenges. This model had more diverse key partners, however, having access to these partners as an end user is challenging, more particularly in terms of getting access to small local networks that are active in installing solar energy technology. These challenges were reflected through the lack of clarity on the selection of beneficiaries. The contact with reliable installers and writing a detailed and competent proposal to receive funding for medium-sized system installations required more clarity to improve the value proposition. Lastly, the challenges micro-finance business models encountered pertained to the lengthy process procedure for acquiring the necessary funding, and the misalignment of visions held by different actors. Although the key resources in this business model resulted in an interactive learning experience among local actors, the revenue streams encounter the challenge of having more bureaucratic procedures to obtain subsidy in addition to the challenge partners have in aligning various initiatives at the national level.

\section{Discussion}

To understand the diffusion of renewable technologies one needs to study the economic, environmental, social, and technical aspects of a technology [62,63]. Engelken et al. [21] showed that research from developing countries focuses on simple business models with attention to financial aspects without addressing many other important pillars of business models. On the contrary, most business model research that focused on industrialized countries revealed complex business models for renewable energy technology, stressing the need to differentiate between business models across regions and economic statuses. In particular, factors driving or hindering renewable energy technology diffusion are highly specific to geographic regions.

By mapping the business models applied and the ongoing challenges in the Lebanon case, we revealed that new business models create opportunities through presenting aspects that are similar to SNM. Both business model development and SNM depend on learning and experimentation (in line with [7]). In this sense, SNM can provide insights to the business models to help them broaden their context of operation and tackle ongoing market challenges.

In a similar vein, the Lebanon case revealed that business models contributed significantly to the development of a solar energy niche market. Whereas the government provided support in the form of financial subsidies, international funders created the knowledge and financial feasibility for installations, and the community initiatives prepared the market to make the shift. Heavy reliance on funders was reduced with micro-finance and alternative business models where local communities and incubation centers focus on creating more individual-based solutions to renewable energy uptake. This was either done through municipalities in small villages, or via entrepreneurs providing solutions to the small-scale barriers. The micro-finance business model was based on customers' decisions to make the investment and on their knowledge. However, this confirms the need to change from a donor-based to a market-based perspective [46,64]. 
The results also show that one of the important aspects in the Lebanese solar market development was the transfer of technical knowhow during local training sessions and workshops from firms and experts from developed countries. The importance of the learning process was also reflected in the shift from donor aid business models to local collective business models. Thus moving away from fully funded models to create more sustainable markets. Therefore, we agree with Doganova et al. [13], who address the importance of communication between different innovation network actors, which enriches the learning process and social network formation, but also succeeds in attracting new investments. Similarly, we agree with Martinot et al. [46] who argue that in order to increase the growth of renewable energy markets in a developing country, an increased technical knowhow is required to develop technologies and the supporting industries. This transfer of knowledge and expertise helped to establish a solid technical ground in the market. Yet, to achieve a sustainable development on the national level, a shift to innovative business models for renewable energies might result in a strong 'business-society relationship' [65]. Addressing the social context, creating more active roles for consumers in the market through business models that address ongoing challenges is a crucial component to sustain solar energy niche markets in Lebanon.

A common approach for business models in developing countries involves targeting the customer side, where products and services match the customers' preferences [24,25], such as social entrepreneurship business models addressing the same customers [3,23]. Another way is by involving consumers as information sources [66] so that users will be more likely to innovate and aid in the development of a certain technology in the market [67]. This segment of users is what Rogers' diffusion of innovation model defines as 'innovators' [68], and emphasizes that users might engage in having different roles such as co-producers (pro-sumers) or innovators [44].

We agree with Huijben and Verbong [7] that in order to achieve higher market uptake of renewable energy technologies, better infrastructure and more customer oriented mechanisms need to be applied. However, the challenge that surrounds certain business models in developing countries is the absence of stable energy supply (often resulting in numerous blackouts) and the lack of a regulatory framework that ensures the promotion of individual and entrepreneurial opportunities in the concept of trading electricity among neighbors or in certain neighborhoods. This situation offers interesting opportunities for more innovative business models with value propositions supporting decentralized technologies and less reliance on inadequate centralized systems. This makes it difficult to implement innovative business models for renewable energy sources into fragile infrastructures [26]. Such is the case pertaining to the unreliable Lebanese electricity grid and the bureaucratic system surrounding it.

Reflecting on the Lebanese solar energy market, a crucial dialogue occurred between a key banking institute and a consumer representative organization. In addition to the bank's core function of providing flexible loan terms to the customer, the banking institutes were indirectly reflecting on the quality of the system by showing the reports to the National Conservation Center, which monitors the entire process. In an effort to target new customers and expand their business models, technology providers highlighted the importance of micro-finance $[46,69,70]$. Micro-finance institutes that are non-governmental organizations (NGOs) act as a point of contact with the end users that not only provide customers with loans, but help firms to identify prospective customers and act as sales channels for renewable energy technology supply [26]. As reflected in the Lebanese case, corporate end users were targeted to provide a feasibility study for the banking institute granting loans for collective solar energy systems in cases where enterprises, municipalities, and non-profit organizations acted as a guarantee for the banks to process the funding.

As shown in the Lebanese case, from a business model perspective, applying a new value proposition might target a different customer segment. The case revealed that the segment of collective solar systems is still emerging, and consumers are not yet in the phase of taking active new roles that will help the niche to develop and scale up. This takes into account the importance of customer needs regarding their social position and lifestyle [52]. 


\section{Conclusions and Implications}

In this paper, two research questions were presented: (1) What are the challenges of business and financial models in the transition towards decentralized solar energy driven systems? And (2) what are the promising opportunities for new business models in a developing country context? In order to answer these two questions, we conducted a literature study and analyzed solar energy niche market development in Lebanon.

Results show that business models used within or even beyond niches represent change and development in markets [2]. By combining insights from transition and business model scholarship, new knowledge can be generated to develop research agendas and support policy makers. Business models through their various components not only have an important role in sustainable transitions in developed countries, but also in developing countries. In the case analyzed, this was observed in various activities that match the shaping of expectations and learning at the niche level.

Key challenges observed in the Lebanon case reflect the importance that should be given to certain business model characteristics. This results in an improvement in the various criteria of business models such as infrastructure management, and addresses product, customer, and financial aspects. As represented in the results section, the locally based and micro-finance business models were creating a higher value for customers and an improvement in the infrastructure and financial components. Besides showing the contribution of the financial components of business models, the results show the importance of enabling entrepreneurs to create new business models given the available financial incentives in markets. In the Lebanon case, it is the promising opportunities of business models that focus on the potential that entrepreneurs have. However, to further insights in a developing country context, new research avenues addressing the role of entrepreneurs in creating knowledge hubs that attract local stakeholders (i.e., consumers and business companies) or organizing frequent discussions that address sustainable consumption tips regarding the use of new technology can be explored.

A particular challenge with the solar niche market development in Lebanon pertained to the unavailability of space. Therefore, it is important to start thinking about initiating projects that involve neighborhoods and households with spacious roofs, that can collectively use or finance a solar PV system, for instance by using community shares. As long as subsidies are high it is not likely that pressure will be created to come up with new market concepts to support higher uptake. Regarding solar PV technology, a shift from a centralized to a decentralized technological paradigm, and a societal shift from passive to active users or 'prosumers' is basically needed. This requires the need to address values in business models. Wainstein and Bumpus [14] showed, for instance, that having new value propositions in place allows for reaching different customer segments, like having shared ownership of collective solar PV. An exemplary business model concept would be that of citizen-led renewable energy cooperatives in which public values like equality, justice, community well-being, and ecological sustainability, but also financial efficiency and yield, apply, using a model in which the cooperative gives out shares and members become shareholders and gain ownership and influence in the governance and decision-making of the cooperative that runs one or more collectively owned solar PV parks [71].

Putting the key elements of business models addressed in the present study in perspective, we argue that prospects in developing countries like Lebanon are primarily based on micro-finance and the roles entrepreneurs take. For instance, the donors were observed to have shifted their expectations to focus on supporting socially oriented private enterprises, providing a key opportunity for new ideas and start-ups. Therefore, we think that political support for entrepreneurs is likely to enable development of new business model concepts. In light of ongoing challenges and the weak and unstable role that (national) governments have, creating a bottom-up social innovation approach will respond closely to community needs and interests. For instance, the need for creating sustainable business models through community-based initiatives-like renewable energy cooperatives-that will be the linking point between finance providers and the end users. The concept of launching large-scale renewable energy producing systems for large groups of end users might also help to solve issues 
pertaining to space availability problem and high investment cost. Yet, due to the individualistic culture that many of the end users have (particularly in Lebanon), setting up community-based initiatives may prove troublesome, especially in urban environments. However, there is a need to establish trust among individuals contributing to this type of initiative. For instance, a future potential business model that involves peer to peer trading was discussed by CEDRO, mentioning that it could have good potential given that the right regulatory scheme is in place. This requires further research to determine the essential technical infrastructure related to information and communication technology. To achieve higher adoption rates in the Lebanese solar energy market, it is important to develop and analyze policy, and for policy makers to select and adopt policy instruments that not only target end users (from the demand side), but also technology suppliers (from the supply side) and other agents in the wider supply chain and socio-technical system.

Limitations to the present study amongst others pertain to the particular country selected as a single case study for research. To address this issue, we recommend a comparison of business models used for solar PV niche market development between multiple developing economies that can provide comprehensive real life examples of common opportunities and pitfalls of business models. In addition, further insights are necessary to address the role consumers and enterprises can play in response to innovative business models. Future research may also address tackling of limitations that customer-centered business models face in developing countries, particularly in relation to the cultural, political, and infrastructure dimensions. Future research could extend the analysis of the present study beyond the financial and knowledge transfer components. Researching interrelations between digitalization and new business models in the renewable energy market might provide useful insights into involving consumers in the transition process in new ways.

Author Contributions: Conceptualization, H.E.; methodology, H.E., T.H.; analysis, H.E., T.H.; data collection, H.E.; writing-original draft preparation, H.E., T.H.; writing-review and editing, T.H., H.E.; visualization, H.E.; supervision, T.H.; funding acquisition, H.E. All authors have read and agreed to the published version of the manuscript.

Funding: This research received no external funding.

Conflicts of Interest: The authors declare no conflict of interest. The funders had no role in the design of the study; in the collection, analyses, or interpretation of data; in the writing of the manuscript, or in the decision to publish the results.

\section{References}

1. Geels, F.W. Technological transitions as evolutionary reconfiguration processes: A multi-level perspective and a case-study. Res. Policy 2002, 31, 1257-1274. [CrossRef]

2. Sarasini, S.; Linder, M. Integrating a business model perspective into transition theory: The example of new mobility services. Environ. Innov. Soc. Transit. 2017, 27, 16-31. [CrossRef]

3. Jolly, S.; Raven, R.; Romijn, H. Upscaling of business model experiments in off-grid PV solar energy in India. Sustain. Sci. 2012, 7, 199-212. [CrossRef]

4. Weiller, C.; Shang, A.; Neely, A.; Shi, Y. Competing and co-existing business models for EV: Lessons from international case studies. Int. J. Automot. Technol. 2015, 15, 126-148. [CrossRef]

5. Geissdoerfer, M.; Doroteya, V.; Evans, S. Sustainable business model innovation: A review. J. Clean. Prod. 2018, 198, 401-416. [CrossRef]

6. Tukker, A. Product services for a resource-efficient and circular economy-A review. J. Clean. Prod. 2015, 97, 76-91. [CrossRef]

7. Huijben, B.; Verbong, G. Breakthrough without subsidies: PV Bussiness Model Experiments in the Netherlands. Energy Policy 2013, 56, 362-370. [CrossRef]

8. Frankel, D.; Ostrowski, K.; Pinner, D. The disruptive potential of solar power. McKinsey Q. 2014. Available online: https://www.mckinsey.com/business-functions/sustainability-and-resource-productivity/ our-insights/the-disruptive-potential-of-solar-power (accessed on 3 February 2020).

9. Hekkert, M.P.; Suurs, R.A.A.; Negro, S.O.; Kuhlmann, S.; Smits, R.E.H.M. Functions of innovation systems: A new approach for analysing technological change. Technol. Forecast. Soc. Chang. 2007, 74, 413-432. [CrossRef] 
10. Teece, D.J. Business Models, Business Strategy and Innovation. Long Range Plan. 2010, 43, 172-194. [CrossRef]

11. Kemp, R.; Schot, J.; Hoogma, R. Regime shifts to sustainability through processes of niche formation: The approach of strategic niche management. Technol. Anal. Strateg. Manag. 1998, 10, 175-195. [CrossRef]

12. Smith, A.; Raven, R. What is protective space? Reconsidering niches in transitions to sustainability. Res. Policy 2012, 41, 1025-1036. [CrossRef]

13. Doganova, L.; Eyquem-Renault, M. What do business models do? Narratives, calculation and market exploration. Res. Policy 2009, 38, 1559-1570. [CrossRef]

14. Wainstein, M.; Bumpus, A. Business Models as Drivers of the Low Carbon Power System Transition: A Multi-Level Perspective. J. Clean. Prod. 2016, 126, 572-585. [CrossRef]

15. Berland, E. Edelman Trust Barometer 2015: Executive Summary; Edelman: New Chicago, IN, USA, 2015.

16. Bidmon, C.M.; Knab, S. The Three Roles of Business Models for Socio-technical Transitions Sebastian Knab. In Proceedings of the XXV ISPIM Conference-Innovation for Sustainable Economy and Society, Dublin, Ireland, 8-11 June 2014.

17. Huijben, J.C.C.M.; Verbong, G.P.J.; Podoynitsyna, K.S. Mainstreaming solar: Stretching the regulatory regime through business model innovation. Environ. Innov. Soc. Transit. 2016, 20, 1-15. [CrossRef]

18. Hansen, U.E.; Nygaard, I.; Romijn, H.; Wieczorek, A.; Kamp, L.M.; Klerkx, L. Sustainability transitions in developing countries: Stocktaking, new contributions and a research agenda. Environ. Sci. Policy 2018, 84, 198-203. [CrossRef]

19. Elmustapha, H.; Hoppe, T.; Bressers, H. Understanding Stakeholders' Views and the Influence of the Socio-Cultural Dimension on the Adoption of Solar Energy Technology in Lebanon. Sustainability 2018, 10, 364. [CrossRef]

20. Elmustapha, H.; Hoppe, T.; Bressers, H. Comparing two pathways of strategic niche management in a developing economy; the cases of solar photovoltaic and solar thermal energy market development in Lebanon. J. Clean. Prod. 2018, 186, 155-167. [CrossRef]

21. Engelken, M.; Römer, B.; Drescher, M.; Welpe, I.M.; Picot, A. Comparing drivers, barriers, and opportunities of business models for renewable energies: A review. Renew. Sustain. Energy Rev. 2016, 60, 795-809. [CrossRef]

22. Gabriel, C.; Kirkwood, J. Business models for model businesses: Lessons from renewable energy entrepreneurs in developing countries. Energy Policy 2016, 95, 336-349. [CrossRef]

23. Bryant, S.; Romijn, H. Not quite the end for Jatropha? Assessing the financial viability of biodiesel production from Jatropha in Tanzania. Energy Sustain. Dev. 2014, 23, 212-219. [CrossRef]

24. Mahama, A. 2012 international year for sustainable energy for all: African Frontrunnership in rural electrification. Energy Policy 2012, 48, 76-82. [CrossRef]

25. Bocken, N.M.P.; Short, S.W.; Rana, P.; Evans, S. A literature and practice review to develop sustainable business model archetypes. J. Clean. Prod. 2014, 65, 42-56. [CrossRef]

26. Harish, S.M.; Raghavan, S.V.; Kandlikar, M.; Shrimali, G. Assessing the impact of the transition to Light Emitting Diodes based solar lighting systems in India. Energy Sustain. Dev. 2013, 17, 363-370. [CrossRef]

27. Schmidt, T.; Blum, N.; Sryantoro, W.R. Attracting private investments into rural electrification-A case study on renewable energy based village grids in Indonesia. Energy Sustain. Dev. 2013, 17, 581-595. [CrossRef]

28. Geels, F.; Raven, R. Non-linearity and expectations in niche-development trajectories: Ups and downs in Dutch biogas development (1973-2003). Technol. Anal. Strateg. Manag. 2006, 18, 375-392. [CrossRef]

29. Geels, F. The impact of the financial-economic crisis on sustainability transitions: Financial investment, governance and public discourse. Environ. Innov. Soc. Transit. 2013, 6, 67-95. [CrossRef]

30. Van der Brugge, J.; Rotmans, R.; Loorbach, D. The transition in Dutch water management. Reg. Environ. Chang. 2005, 5, 164-176. [CrossRef]

31. Verbong, G.P.J.; Beemsterboer, S.; Sengers, F. Smart grids or smart users? Involving users in developing a low carbon electricity economy. Energy Policy 2013, 52, 117-125. [CrossRef]

32. Schot, J.; Geels, F.W. Strategic niche management and sustainable innovation journeys: Theory, findings, research agenda; policy. Technol. Anal. Strateg. Manag. 2008, 20, 537-554. [CrossRef]

33. Edquist, C. Reflections on the systems of innovation approach. Sci. Public Policy 2004, 31, 485-489. [CrossRef]

34. Geels, F.W. Ontologies, socio-technical transitions (to sustainability); the multi-level perspective. Res. Policy 2010, 39, 495-510. [CrossRef] 
35. Bidmon, C.M.; Knab, S.F. The three roles of business models in societal transitions: New linkages between business model and transition research. J. Clean. Prod. 2018, 27, 903-916. [CrossRef]

36. Korhonen, J.; Seager, T. Beyond Eco-Efficiency: A Resilience Perspective. Bus. Strateg. Environ. 2008, 17, 411-419. [CrossRef]

37. IEA. Capturing the Multiple Benefits of Energy Efficiency: Exectuvie Summary 2014. Available online: https://www.oecd-ilibrary.org/energy/multiple-benefits-of-energy-efficiency_9789264220720-en (accessed on 3 February 2020).

38. Chesbrough, R.; Rosenbloom, H. The role of the business model in capturing value from innovation: Evidence from Xerox Corporation's technology spin-off companies. Ind. Corp. Chang. 2002, 11, 529-555. [CrossRef]

39. DaSilva, C.M.; Trkman, P. Business model: What it is and what it is not. Long Range Plan. 2014, 47, 379-389. [CrossRef]

40. Zott, C.; Amit, R. Business model design: An activity system perspective. Long Range Plan. 2010, 43, $216-226$. [CrossRef]

41. Osterwalder, A. The Business Model Ontology-A Proposition in a Design Science Approach. Ph.D. Thesis, Universite de Lausanne, Lausanne, Switzerland, 2004.

42. Osterwalder, A.; Pigneur, Y. Business Model Generation: A Handbook for Visionaries, Game Changers; Challengers; Wiley Desktop Editions: Hoboken, NJ, USA, 2010.

43. Tolkamp, J.; Huijben, J.C.C.; Mourik, R.; Verbong, G.P.; Bouwknegt, R. User-Centred Business Model Innovation for Energy Efficiency: A Literature Review. J. Clean. Prod. 2018, 182, 755-764. [CrossRef]

44. Provance, M.; Donelly, R.; Carayannis, E. Institutional influences on business model choice by new ventures in the microgenerated energy industry. Energy Policy 2011, 39, 5630-5637. [CrossRef]

45. Martinot, E.; Chaurey, A.; Lew, D.; Moreira, J.R.; Wamukonya, N. Renewable Energy Market in Developing Countries. Annu. Rev. Energy Environ. 2002, 27, 309-348. [CrossRef]

46. Boons, F. Business Model for Sustainability Innovation: Conceptual Foundations and The Case of Solar Energy. Ph.D. Thesis, Leuphana University of Luneburg, Luneburg, Germany, 2013.

47. Koubaa, S. Renewable energy through the lens of entrepreneurship theory-The case of Morocco. Projectics/Proyectica/Projectique 2017, 3, 69-88. [CrossRef]

48. McGrath, R.G. Business Models: A discovery driven approach. Long Range Plan. 2010, 43, 247-261. [CrossRef]

49. Sosna, M.; Trevinyo-Rodríguez, R.; Velamuri, S.R. Business model innovation through trial-and-error learning: The naturhouse case. Long Range Plan. 2010, 43, 383-407. [CrossRef]

50. Verhees, B.; Verbong, G.P.J. Users, Consumers, Citizens: A systematic review of their roles in sustainability transitions. Eindhoven 2015, 201504, 1-39.

51. Van der Werff, E.; Steg, L. One model to predict them all: Predicting energy behaviours with the norm activation model. Energy Res. Soc. Sci. 2015, 98, 8-14. [CrossRef]

52. Boork, M.; Thomtén, M.; Brolin, M. Key success factors and barriers to end user engagement in smart grid projects. In Proceedings of the BEHAVE 2014 Behaviour and Energy Efficiency Conference, Oxford, UK, 3-4 September 2014; Energy Saving Trust and UK Energy Research Centre (UKERC): London, UK; pp. 1-10.

53. Flyvbjerg, B. Five Misunderstandings About Case Study Research. Qual. Inq. 2006, 12, 219-245. [CrossRef]

54. Yin, R. Case Study Research, 5th ed.; Sage Publications: Los Angeles, CA, USA, 2014.

55. Dóci, G.; Vasileiadou, E.; Petersen, A.C. Exploring the transition potential of renewable energy communities. Futures 2015, 66, 85-95. [CrossRef]

56. Ockwell, D. Can Pay-As-You-Go, Digitally Enabled Business Models Support Sustainability Transformations in Developing Countries? Outstanding Questions and a Theoretical Basis for Future Research. Sustainability 2019, 11, 2105. [CrossRef]

57. Jablonski, S.; Tarhini, M.; Touati, M.; Garcia, D.G.; Alario, J. The Mediterranean Solar Plan: Project proposals for renewable energy in the Mediterranean Partner Countries region. Energy Policy 2012, 44, 291-300. [CrossRef]

58. Tsikalakis, A. Review of best practices of solar electricity resources applications in selected Middle East and North Africa (MENA) countries. Renew. Sustain. Energy Rev. 2011, 15, 2838-2849. [CrossRef]

59. Thornton, W. Strategic Niche Management of the Solar Electricity Sector in Lebanon; UNDP: Beirut, Lebanon, 2016.

60. Brikci, N.; Green, J. A Guide to Using Qualitative Research Methodology; Médecins Sans Frontières: London, UK, 2007.

61. Yin, R.K. Case Study Research: Design and Methods; Sage Publications: Los Angeles, CA, USA, 2009; Volume 5. 
62. Kinab, E.; Elkhoury, M. Renewable energy use in Lebanon: Barriers and solutions. Renew. Sustain. Energy Rev. 2012, 16, 4422-4431. [CrossRef]

63. Harajli, H.; Obeid, J.; Nassab, C. Techno-Financial Appraisal of Rooftop Photovoltaic (PV) Systems: The Case of Lebanon; UNDP: Beirut, Lebanon, 2016.

64. UNDP. Small Decentralized Renewable Energy Power Generation; UNDP: Beirut, Lebanon, 2014.

65. Escobar, L.; Vredenburg, H. Multinational oil companies and the adoption of sustainable development: A resource-based and institutional theory inter- pretation of adoption heterogeneity. J. Bus. Ethics 2011, 98, 39-65. [CrossRef]

66. Cui, A.; Wu, F. Utilizing customer knowledge in innovation: Antecedents and impact of customer involvement on new product performance. J. Acad. Mark. Sci. 2016, 44, 516-538. [CrossRef]

67. Oliveira, P.; von Hippel, E. Users as service innovators: The case of banking services. Res. Policy 2011, 40, 806-818. [CrossRef]

68. Rogers, E.M. Diffusion of Innovation, 5th ed.; Free Press: New York, NY, USA, 2003.

69. Balachandra, P.; Reddy, B.S.; Balachandra, P. Commercialisation of Sustainable Energy Technologies. Renew. Energy 2010, 35, 1842-1851. [CrossRef]

70. Singh, A. Informal markets for electricity: Economics of lighting for hawkers in India. Int. J. Energy Sect. Manag. 2009, 3, 308-323. [CrossRef]

71. Coenen, F.; Hoppe, T.; Chalkiadakis, G.; Akasiadis, C.; Tsoutsos, T. Exploring energy saving policy measures by renewable energy supplying cooperatives (REScoops). In Proceedings of the ECEEE Summer Study Proceedings, Presqu'île de Giens, Hyères, France, 29 May-3 June 2017; 2-159-17. pp. 381-391.

(C) 2020 by the authors. Licensee MDPI, Basel, Switzerland. This article is an open access article distributed under the terms and conditions of the Creative Commons Attribution (CC BY) license (http://creativecommons.org/licenses/by/4.0/). 